\title{
A GYERMEKTELENSÉG MINTÁZATAI A MAGYAR FÉRFIAK KÖRÉBEN
}

\section{PATTERNS OF CHILDLESSNESS AMONG HUNGARIAN MEN}

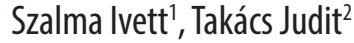 \\ ${ }^{1} \mathrm{PhD}$ \\ Szalma.lvett@tk.mta.hu \\ ${ }^{2} \mathrm{PhD}$, Magyar Tudományos Akadémia \\ Társadalomtudományi Kutatóközpont Szociológiai Intézet \\ Takacs.Judit@tk.mta.hu
}

\begin{abstract}
ÖSSZEFOGLALÁS
Ebben az írásban összefoglaljuk a férfiak gyermektelenségéhez kapcsolódó kutatásaink legfontosabb eredményeit. Bemutatjuk, hogy a férfiak és a nők gyermektelensége mögött gyakran eltérő tényezők húzódhatnak meg, vagy az azonos tényezők mögött eltérő mechanizmusok játszanak szerepet. Kitérünk arra is, hogy a kvalitatív kutatások milyen új eredményekkel gazdagították a férfiak gyermektelenségével kapcsolatos tudásunkat a kvantitatív elemzésekhez képest.
\end{abstract}

\section{ABSTRACT}

In this paper we summarize the most important results of our previous empirical analyses related to male childlessness. We emphasize that different factors can often be detected behind male and female childlessness, or in some cases the same factors can influence the childlessness patterns of the different genders via various mechanisms. We provide new insights into male childlessness in Hungary revealed by our qualitative approach.

Kulcsszavak: gyermektelenség, tudatos gyermektelenség, férfiak, Magyarország, kvantitatív, kvalitatív vizsgálatok, diszkrimináció

Keywords: childlessness, voluntary childlessness, male, Hungary, quantitative and qualitative methods, discrimination

\footnotetext{
${ }^{1}$ A tanulmány megírását az NKFIH (PD 123789) támogatta.
} 


\section{BEVEZETÉS}

A gyermektelenséggel kapcsolatos kutatások többsége a nőkre fókuszál, miközben a gyermektelenek aránya magasabb a férfiak, mint a nők körében, nemcsak Magyarországon, hanem szinte valamennyi európai országban. Magyarországon például a 2001-es népszámlálási adatok szerint a 41 év feletti nők körében 7,8\% volt a gyermektelenek aránya, ami 2011-re 11,2\%-ra növekedett (Kapitány, 2015). Ez az arány a férfiak esetében a 41 és 45 év közötti korcsoportban 2001 és 2011 között 17\%-ról 22\%-ra növekedett (Kapitány, 2015). A számok tükrében jogosan merül fel a kérdés, vajon miért kíséri viszonylag kevés figyelem a gyermektelenség vizsgálatát a férfiak körében.

Erre a kérdésre egyrészt az lehet a válasz, hogy a gyermekvállalás kérdését hajlamosak vagyunk a nőkhöz rendelni, vagyis azt feltételezzük, hogy a nők egyedül hoznak döntést ebben a kérdésben, vagy legalábbis ők a fő döntéshozók. Másrészt a férfiak szülővé válása kevésbé kötődik életkori korlátokhoz, illetve normákhoz, mint a nők gyermekvállalása, ezért nehezebb meghatározni, hogy mikortól tekintünk ténylegesen gyermektelennek egy férfit. Harmadrészt a kérdőíves kutatások esetenként pontatlanabb adatokkal szolgálhatnak a férfiak, mint a nők gyermekvállalásáról: előfordulhat például, hogy egyes férfiak esetleg nem is tudnak arról, hogy gyermekük született, illetve esetenként elfelejthetik megemlíteni nem velük egy háztartásban élő gyermeküket egy kérdőíves vizsgálat során.

Jelen tanulmány célja, hogy áttekintést nyújtson a gyermektelenségre fókuszáló magyarországi kutatásaink föbb eredményeiröl, különös tekintettel az eddig kevéssé kutatott férfi gyermektelenségi mintázatokra, melyeket a női gyermektelenségi mintázatokkal való összehasonlítás tükrében tekintjük át. Először a kvantitatív kutatásaink eredményeit ismertetjük (Szalma-Takács, 2012; 2015), majd ezt követően a kvalitatív kutatásokból származó eredményeket mutatjuk be (Szalma-Takács, 2014; 2018). Tanulmányunkat az eredmények összegzésével és a jövőbeli lehetséges kutatási irányok felvázolásával zárjuk.

\section{KVANTITATÍV KUTATÁSOK}

A gyermektelenség kérdéskörére fókuszáló kutatásaink során először korábbi kérdőíves vizsgálatok eredményeinek másodelemzésével vizsgáltuk, hogy milyen okok állhatnak annak hátterében, ha valaki nem vállal gyermeket Magyarországon (Szalma-Takács, 2012; 2015). Ehhez az Életünk fordulópontjai társadalmi-demográfiai panel-adatfelvételt használtuk, melyet a KSH Népességtudományi Kutatóintézete végzett több mint 16 ezer válaszadó részvételével az első hullámban, ami a vizsgált téma szempontjából Magyarország legnagyobb adatfelvételének számít. A 2002-es első hullámtól egészen a 2008/2009-es harmadik 
hullámig követtük a 30 és 45 év közötti gyermektelen nők, valamint a 33 és 50 év közötti gyermektelen férfiak adatait a gyermekvállalás szempontjából. Az eredmények azt mutatták, hogy mind a férfiak, mind nők körében a gyermektelenül maradás egyik fó - ha nem a legfőbb - meghatározó tényezője az, hogy sikerül-e az érintetteknek tartós párkapcsolatot kialakítaniuk. Emellett a gazdasági tényezők is jelentős szerepet kaphattak, miközben az értékek (a családdal kapcsolatos attitüdök vagy a vallásosság) változása nem befolyásolták jelentősen a szülővé (nem)válással kapcsolatos döntéseket.

E kutatás ugyanakkor rávilágított arra is, hogy miközben számos közös tényező áll a nők és a férfiak gyermekvállalása (illetve nemvállalása) mögött, azért számottevő eltérések is megfigyelhetők. Például míg a gyermektelen nők körében a magas iskolai végzettségüek felülreprezentáltak, addig a férfiak körében az alacsony iskolai végzettségűek között találunk magasabb arányban olyanokat, akiknek nem született gyermekük.

\section{KVALITATÍV KUTATÁSOK}

A korábban említett kvantitatív vizsgálatokat később, 2014 és 2015 között kiegészítettük interjús kutatással. Elöször 40 év feletti gyermektelen nőkkel készítettünk félig strukturált életútinterjúkat annak érdekében, hogy feltárjuk, milyen okok vezethetnek gyermektelenséghez a magyar nők körében (Szalma-Takács, 2014). Majd e kvalitatív kutatást folytattuk 2016-ban harminc 50 év feletti gyermektelen heteroszexuális férfi meginterjúvolásával.

Ezek az interjús vizsgálatok is alátámasztották, hogy jelentős különbségek találhatóak a nők és a férfiak gyermektelenségi mintázatai között. Eredményeink alapján az is elmondható, hogy bár sokszor ugyanazok a tényezők húzódnak meg a férfi és a női gyermektelenség mögött, ezek gyakran eltérő mechanizmusokon keresztül érvényesülnek. A következő alfejezetben egy-egy példát mutatunk be az azonos tényezők mögött meghúzódó mechanizmusokra.

\section{Partnerkapcsolat}

A nemzetközi és a hazai kutatások kimondott vagy kimondatlan alapvetése, hogy a stabil párkapcsolat megléte elengedhetetlen a gyermekvállaláshoz nők és férfiak számára egyaránt (Jalovaara-Fasang, 2017; Szalma, 2016). A nőkkel folytatott interjús vizsgálatok ezt az eredményt annyiban finomították, hogy a párkapcsolat megléte mellett annak minősége sem elhanyagolható tényezö. A férfiakkal készített interjúk során kiderült, hogy körükben ritkán fordult elő, hogy valaki egyetlen tartós párkapcsolatot sem tudott kialakítani az élete folyamán. Így az életút-megközelítés nem igazolta, hogy a férfiaknál a partnerkapcsolat hiánya 
lenne gyermektelenségük egyik vagy fö meghatározó tényezője. Ráadásul az általunk kérdezett párkapcsolatban élő férfiak a kapcsolataik minőségével is elégedettebbeknek mutatkoztak, mint női interjúalanyaink. Azaz róluk nem mondható el, hogy partnerkapcsolatuk nem megfelelő minősége miatt nem szerettek volna gyermeket vállalni. A párkapcsolatban élő férfiak számára a gyermekvállalás akadályai közé tartozhatott, ha idősebb párt választottak, akinek már biológiailag nem lehetett gyermeke, illetve ha a partnerüknek már volt(ak) gyermeke(i), és nem szeretett volna több gyermeket vállalni. Különösen az alacsonyabb iskolai végzettségü férfiak számoltak be ezekről az akadályokról.

\section{Életkor}

Kvantitatív vizsgálataink rávilágítottak arra, hogy az életkor előrehaladta jelentős szerepet játszott abban, hogy a gyermekvállalást (átmenetileg) halasztók végül mégsem tudták megvalósítani eredeti gyermekvállalási elképzeléseiket. Például az általunk vizsgált - 2001 és 2008 közötti - időszakban a gyermekvállalást halasztó 30-45 éves nőknek és 33-50 éves férfiaknak csak egy kis része volt képes arra, hogy megvalósítsa gyermekvállalási terveit: a vizsgált nőknek mindössze $22 \%$-a, a férfiaknak pedig csak 14\%-a vált szülővé 2008-ra (Szalma-Takács, 2012). A 45 éves vagy ennél idősebb nők esetében ez az eredmény akár véglegesnek is tekinthető a női reprodukciós aktivitás biológia korlátai miatt, melyek már 35 éves kortól kezdve éreztetik egyre erősödő hatásukat. Az életkorral összefüggő biológiailag meghatározott korlátok mellett beszélhetünk a gyermekvállalás társadalmi normák által keretezett életkori határairól is - azaz arról a társadalmilag meghatározott jellemzőről, hogy egyes társadalmi csoportokban kit tartanak „túl öregnek" ahhoz, hogy gyermeket vállaljon -, melyek hasonlóan hatnak a férfiakra, mint a nőkre. Interjús vizsgálataink eredményei azonban rávilágítottak arra, hogy a különböző társadalmi csoportokhoz tartozó férfiak körében eltérö társadalmi normák érvényesülhetnek: például a magasabb iskolai végzettségü és jobb anyagi helyzetü interjúalanyaink arról számoltak be, hogy elképzelhetőnek tartják, illetve nem tartják kizártnak, hogy első gyermeküket majd az ötvenes éveik végén vagy akár valamikor a hatvanas éveikben fogják vállalni. Ezzel szemben alacsonyabb iskolai végzettségủ társaik már nem vállalkoztak volna erre 50 évesen, és az is kiderült, hogy még a negyvenes éveikben is túl késeinek tűnt volna többek számára az apává válás.

\section{Anyagi helyzet}

Az anyagi tényezők szintén némileg eltérő mechanizmusokon keresztül vezettek gyermektelenséghez a nők és a férfiak körében. Míg a nőknél a bizonytalan munkalehetőségek és a rossz anyagi helyzet elsősorban azt akadályozta meg, hogy 
azok a nők, akik nem találtak maguknak megfelelő partnert, belevágjanak - akár egyedül is - a gyermekvállalásba, a férfiak számára ugyanezek a tényezők már a partnerkapcsolat kialakítását - és ezáltal közvetetten a szülővé válást - is megnehezíthették. Mindez egybevág azzal a Magyarországon uralkodó tradicionális nemiszerep-elvárással, miszerint egy heteroszexuális nukleáris családban elsősorban a férfinak kell(ene) a családfenntartó, fö kenyérkereső szerepét ellátni. Ezenfelül férfi interjúalanyaink körében arra is akadt példa, hogy az átlagon felüli anyagi helyzet akadályozta a partnerkapcsolat kialakítását és a gyermekvállalást: ez esetben az érintett azt tartotta kockázatosnak, hogy egy esetleges válás következtében elveszítheti felhalmozott vagyonát, így inkább tartózkodott a partnerkapcsolatoktól.

\section{Ú ELEMEK SZEREPE A FÉRFIAK GYERMEKTELENSÉGÉBEN}

Az eddig példaszerűen illusztrált tényezők mellett új - a nők körében nem kimutatható vagy kevésbé hangsúlyos - okok is feltüntek a férfiakkal készült interjúkban.

\section{Egészségügyi okokhoz köthető gyermektelenség}

A kérdőíves vizsgálatok - egyrészt a téma érzékenysége, másrészt az alacsony elemszám miatt - nem teszik lehetővé, hogy az egészségügyi okokra visszavezethető gyermektelenséget részletesen elemezzük. A kvalitatív vizsgálatokból azonban megállapítható, hogy míg a női interjúalanyaink több mint egyharmada beszámolt olyan egészségügyi okról, amely megnehezítette (volna) a gyermekvállalást, addig a férfiaknál senki sem számolt be hasonló egészségügyi problémáról. Miközben az általunk készített szakértői interjúkban a termékenységi kérdésekre specializálódott orvosok kiemelték, hogy az utóbbi évtizedekben a férfiak terméketlensége egyre nagyobb méreteket ölt.

Egyetlen interjúalanyunk esetében, egy falun élő, alacsony iskolai végzettségü 70 éves férfinél merült fel a gyermekvállalást akadályozó egészségügyi probléma létezése, de a témát tabuként kezelve nem beszélt erröl bővebben. Ugyanakkor az általános rossz egészségi állapot a férfiak körében kiemelkedő szerepet kapott: az alacsonyabb iskolai végzettségü férfiak magasabb iskolai végzettségü társaikhoz képest mintegy húsz évvel korábbi időpontot adtak meg a gyermekvállalás még lehetséges életkoraként. Ez a korlátozóbb életkori norma szorosan összefügghet azzal, hogy az iskolai végzettség szerint Magyarországon a legnagyobb a szakadék a várható átlagos élettartamok között: alacsonyan iskolázott társaikhoz viszonyítva átlagosan kilenc évvel élnek tovább a magas iskolai végzettségüek (OECD, 2017). Ugyanakkor az általunk vizsgált nőknél nem jelentkeztek jelentős különb- 
ségek a gyermekvállalás még lehetséges életkori normájában iskolai végzettség szerint (Szalma-Takács, 2014).

\section{A tudatos gyermektelenség felvállalása}

Kiemelendö, hogy a férfiakkal készített interjúkban sokkal markánsabban jelent meg a tudatos gyermektelenség, mint a nőknél. A nők körében kevés olyan interjúalannyal találkoztunk, aki tudatosan nem szeretett volna gyermeket vállalni: e kevés kivétel pedig mind a magas iskolai végzettségü, jobb társadalmi helyzetü nők közül került ki. A férfiak nyíltabban beszéltek arról, hogy valójában soha nem szerepelt a terveik között az apává válás. Ráadásul nemcsak a magas iskolai végzettségü férfiak fogalmazták meg ezt, hanem az alacsonyabban iskolázott férfiak körében is találkoztunk olyannal, aki szándékosan választotta a gyermek nélküli életet. Ez nem feltétlenül jelenti azt, hogy a nőkhöz képest több férfi lenne, aki nem szeretne gyermeket: lehetséges, hogy ez a különbség abból fakad, hogy a férfiak szabadabban felvállalhatják a gyermektelenség tudatos választásával kapcsolatos véleményüket nemcsak egy kérdőíves vizsgálat keretében, de egy interjús vizsgálat során is. Mindez összefügghet azzal, hogy a szülői gondoskodás még mindig inkább a nőkhöz köthető szerepként jelenik meg, valamint a közvélekedés úgy ítéli meg, hogy egy nő nem élhet teljes életet gyermek nélkül, míg a férfiakkal szemben kevésbé szigorú társadalmi normák vannak érvényben a gyermekvállalást tekintve (Szalma, 2014).

\section{HÁTRÁNYOS HELYZETÜEK-E A GYERMEKTELEN FÉRFIAK?}

Végezetül egy olyan érzékeny témát villantunk fel, amely szintén nehezen vizsgálható kérdőíves módszerekkel: a gyermektelenekkel szembeni diszkrimináció kérdését. A téma vizsgálata különösen fontos egy olyan tradicionálisan pronatalista társadalomban, ahol a gyermekvállalás kérdése a napi politikai diskurzusnak is része. Az interjúk során arra is rákérdeztünk, hogy az interjúalanyaink milyen előnyöket, illetve hátrányokat tapasztaltak munkájuk során, illetve a magánéletükben azzal kapcsolatban, hogy nem született gyermekük. E tekintetben is több különbséget találtunk a női és a férfi interjúalanyok beszámolói között: míg az alacsony iskolai végzettségủ nők nem tudtak konkrét előnyökről beszámolni, addig magas iskolai végzettségü társaik a munkában elért sikereket könyvelték el gyermektelenségükkel összefüggésbe hozható előnyként. A férfiak körében azonban éppen az alacsonyabb iskolai végzettségủek számoltak be a gyermektelenség egyik előnyéről: a kötetlenebb életforma választásának a lehetőségéröl. Mivel az alacsony iskolai végzettségü - főként különféle szakmunkákat végző - férfiak számára a munkához köthető mobilitás jelentette az egyetlen 
lehetőséget arra, hogy utazzanak, így fontos volt számukra, hogy olyan munkát vállalhattak, amely akár heti vagy havi ingázással járt, ez pedig nehezebben lett volna összeegyeztethető a helyhez kötöttebb gyermekes életmóddal (SzalmaTakács, 2018).

Míg a munkájukkal kapcsolatban férfi interjúalanyaink nem számoltak be hátrányokról, addig a magánélet területén diszkriminációként élték meg a környezetük részéről tapasztalt negatív elóítéleteket. Ha egy bizonyos életkor felett egy férfinek nincs gyermeke, akkor interjúalanyaink tapasztalatai szerint esetleg azt gondolhatják róla, hogy impotens, meleg vagy drogfüggő. Ezen negatív elöitéletek ellen interjúalanyaink úgy próbáltak védekezni, hogy távolságot tartottak közvetlen környezetüktöl, és nem engedtek betekintést a magánéletükbe; de akadt köztük olyan is, aki a találgatásokat rövidre zárva a „sajnos nincs gyerekem" kifejezés használatával utalt arra, hogy - talán - egészségügyi okok állhatnak gyermektelensége hátterében (Szalma-Takács, 2018).

\section{ÖSSZEGZÉS}

A kvantitatív adatok másodelemzése rávilágított arra, hogy érdemes interjús vizsgálatokat is végeznünk annak érdekében, hogy jobban megértsük a Magyarországon jellemző gyermektelenségi mintázatokat. A gyermektelen férfiakkal folytatott interjús vizsgálatunk úttörő abban a tekintetben, hogy korábban még nem vizsgálták a férfiak gyermektelenségét Magyarországon kvalitatív módszerekkel. A kutatási eredmények azt mutatták, hogy a férfiak és a nők gyermektelensége mögött eltérő tényezők húzódhatnak meg. A férfiak között például nagyobb arányban találtunk olyanokat, akik szándékosan nem akartak gyermeket vállalni. Ugyanakkor azt is be tudtuk mutatni, hogy még az azonos tényezők is különbözö mechanizmusokon keresztül érvényesülhettek a nemek között. A kvalitatív vizsgálat továbbá lehetővé tette, hogy betekintést nyerjünk abba, hogy milyen elöitéletekkel kell szembenézniük a gyermektelen nőknek és férfiaknak.

Eddigi elemzéseink során azonban a gyermektelenséghez köthető számos kérdést még nem tárgyaltunk. Érdemes lenne például azt vizsgálni, hogy milyen a férfiak attitüdje azzal kapcsolatban, hogy egyedül vállaljanak gyermeket, akár örökbefogadás útján. Szintén nem állt módunkban azt elemezni, hogy milyen a kapcsolatuk azokkal a gyerekekkel, akikkel egy háztartásban élnek, de nem vér szerinti leszármazottaik - hiszen a férfiaknál nagyobb arányban fordulhat elö, hogy ideiglenesen apai szerepet vállalhatnak gyermekes partnerrel való együttélésük során. Mindezek alapján a férfiak gyermektelensége még inkább képlékenynek tủnhet, mint a nőké: nem csupán biológiai, de társadalmi okokra visszavezethetően is. 


\section{IRODALOM}

Jalovaara, M. - Fasang, A. E. (2017): From Never Partnered to Serial Cohabitors: Union Trajectories to Childlessness. Demographic Research, 36, 1, 1703-1720. DOI: 10.4054/DemRes.2017.36.55

Kapitány B. (szerk.) (2015): Terjed a gyermektelenség Magyarországon. Korfa Népesedési hirlevél, XV, 1, 1-4. http://demografia.hu/kiadvanyokonline/index.php/korfa/article/downlo$\mathrm{ad} / 1299 / 734$

OECD (2017): State of Health in the EU. Hungary. Country Health Profile 2017. http://www.euro. who.int/_data/assets/pdf_file/0006/355983/Health-Profile-Hungary-Eng.pdf?ua=1

Szalma I. (2014): A gyermekvállalás társadalmi normái és a mesterséges megtermékenyítéssel kapcsolatos attitüdök vizsgálata Magyarországon és Európában. Replika, 85-86, 35-57. http:// replika.hu/system/files/archivum/85-86_03_szalma.pdf

Szalma I. (2016): Partnerships Norms and Childlessness in Hungary and Transylvania in European View. Belvedere Meridionale, 28, 2, 66-81. http://www.belvedere-meridionale.hu/wp-content/ uploads/2016/02/05_Szalma_Belvedere\%20Meridionale_2016-2_pp66-81.pdf

Szalma I. - Takács J. (2012): A gyermektelenséget meghatározó tényezők Magyarországon. Demográfia, 55, 1, 44-68. http://www.demografia.hu/kiadvanyokonline/index.php/demografia/ article/view/439/583

Szalma I. - Takács J. (2014): Gyermektelenség - és ami mögötte van. Egy interjús vizsgálat eredményei. Demográfia, 57, 2-3, 109-137. http://www.demografia.hu/kiadvanyokonline/index. php/demografia/article/view/2477/2334

Szalma I. - Takács J. (2015): Who Remains Childless? Unrealized Fertility Plans in Hungary. Czech Sociological Review, 51, 6, 1047-1075. http://sreview.soc.cas.cz/uploads/13dd14ac8d152b92333c8193cc217596a08173ee_15-6-08Szalma23.indd.pdf

Szalma I. - Takács J. (2018): Is There Voluntary Childlessness at All in Hungary? In: Natalie Sappleton (ed.): Voluntary and Involuntary: The Joys of Otherhood? Emerald Publishing Limited, 309-337. https://www.researchgate.net/publication/326710775_Is_There_Voluntary_Childlessness_At_All_in_Hungary 